\title{
The Effect of Class Management on Grade Five Students Learning Outcome At State Primary School Number 066654 Kelambir V District Tanjung Gusta Medan Helvetia
}

\section{Panni Ance Lumbantobing ${ }^{1}$, Ruth Donda Eleonora Panggabean², Maria Friska Nainggolan ${ }^{3}$}

Universitas Sari Mutiara, Medan, Indonesia

panniance@yahoo.com

\section{Abstract}

This study aims to investigate the effect of classroom management on student learning outcomes at class five primary school numbers 066655, distrcit of Kelambir V Tanjung Gusta Medan Helvetia academic year 2019/2020. The analysis technique in this study is a simple regression technique, observing the relationship or effect between variables. The sample of this research is students of class state primary school number 066654 district of Kelambir V Tanjung Gusta Medan Helvetia, which consists of 2 classes, namely class $V$ A totaling 28 students and class $V B$ totaling 28 students. The total number of class $V$ is 56 students. The variable instrument in the study is all valid, while the reliability for all variables is reliable. Based on the results of statistical analysis, it shows that simple linear regression analysis with the regression equation $Y=24.281+0.896 X$ forms a linear line and coefficient of regression direction means. The calculation result is obtained Fcount 56.912 in consultation with Ftable for an error rate of $5 \%, F$ table $=4.02$. Thus Fcount $>$ F table $(56.912>4.02)$ for an error level of 5\%. Based on the results of the F test calculation, Fcount is 56.912 with sig $=0.000<0.005$ so that $\mathrm{Ho}$ is rejected and $\mathrm{Ha}$ is accepted, which means there is an effect of class management $(X)$ which is significant towards learning outcomes $(Y)$. This means that the better the classroom management carried out by the teacher, the higher the student learning outcomes.
Keywords

class management; learning outcomes; primary school

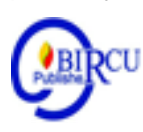

\section{Introduction}

Education cannot be separated from humans as it is the key of human future education equipped by reason and thoughts. Education has an important role in human life since it can guarantee the development and continuity of humans in all aspects of their personality and life. Sugiharto (2020) stated that education is one of the efforts to improve the ability of human intelligence, thus he is able to improve the quality of his life. So, to create the highest quality of human resources, education is becoming an important factor to be considered.

Furthermore, education is the main key to the realization of superior and quality human resources, so that they can compete with other countries in this millennial era. In this case, one of teachers' duties as an educator in elementary schools is to distribute information in the form of knowledge which is used as provisions for students to be able to 
attend secondary education. The knowledge provided in elementary schools is in the form of exact and non-exact science. Exact sciences are Mathematics and Natural Sciences (IPA), while non-exact sciences are Social Sciences (IPS), Citizenship Education (PPkn), Cultural Arts and Crafts (SBdP), and Indonesian Language. These subjects have been integrated into one learning in the 2013 curriculum, namely thematic learning.

A teacher should be able to guide students to be active in learning activities and to create a pleasant atmosphere and interaction in the class. One of the skills that teachers must have is class management skills, considering that the teacher's duty in class is to teach students by trying to optimal learning conditions according to the learning objectives to be achieved.

The main problem faced by teachers is classroom management. The most aspect is often discussed by professional writers and by teacher deals with classroom management. Due to classroom management is a complex behavioral problem. Teachers use it to create and maintain classroom conditions in such a way that students can achieve teaching goals efficiently and enable them to learn. Class management consists of two words, namely management and class.

Class management is the teachers' skill to create and maintain optimal learning conditions and restore them if there is a disruption in the teaching and learning process (Syaiful and Aswan, 2006: 173). In other words, it deals with the activities to create and maintain optimal conditions for teaching and learning. The examples are stopping the behavior of students who divert class attention, giving reward for the punctuality of completing assignments by students, and establishing productive group norms.

An optimal learning condition can be achieved if the teacher is able to manage students and control them in a pleasant atmosphere to achieve teaching goals. Moreover, a good interpersonal relationship between teachers and students and students with students is a requirement for successful classroom management. Effective classroom management is an absolute prerequisite for an effective teaching and learning process. Every teacher deals with two main problems, namely teaching and management problems. Teaching problems are efforts to help students achieve specific teaching goals directly, for example creating lesson units, presenting information, asking questions, evaluating, and so on.

One indicator of learning success is viewed from the learning outcomes achieved by students. Learning outcomes or achievements are the realization or expansion of potential skills or capacities that a person has (Sukmadinata, 2005: 102). In line with this, Shah (2008: 15) states that ideal learning outcomes include all psychological domains that change as a result of the experience and learning process of students. Student learning outcomes show the level of student understanding of the material being studied. To achieve good results, it is necessary optimal classroom management. So, it can be concluded that if the teacher has implemented classroom management well, it will have an impact on increasing student learning outcomes.

In accordance with the results of the preliminary survey through conversation with the teacher, the problems in state primary school number 066654 is the class $\mathrm{V}$ teacher says that in class management has been conducted but there are still some problems that occur in the classroom. The relationship between teachers and students is not comprehensive enough to cause deviant student behavior during the learning process. For example, it is found that a number of students are getting sleepy, paying less attention to the teacher, eating in class, and making noise during learning so it lead to less active teaching and learning process 
Class management applied by the teacher has obstacles and disturbance in teaching activities. It is teaching methods for instances, the use of media is still less due to the limited facilities available, the lack of enthusiasm of students in taking lessons so that students chat with their friends, the noisy atmosphere in class room make ineffective and inconvenient teaching and learning process. In addition, some teachers do not really carry out classroom management because they are considered to be troublesome and timeconsuming, so that learning is neglected.

There are three factors that influence classroom management according to Karwati and Donni (2018), namely the Physical Environment which is further divided into four parts, including (a) The room where the teaching and learning process takes place. Student room at state primary school number 066654 is suitable for use because the number of students is not too many in each room so that they do not jostle and can move freely. In addition, in each class it has also used decorations that have educational value. It adds to the beauty of the classroom. The decoration is also the result of work done by students, through assignments given by the teacher in several related subjects. (b) Arrangement of seat, it is difficult to do because the teacher still learns to condition it according to the character of the students. In order to allow face-to-face contact between students and teachers when learning, it is no longer difficult for teachers to pay attention to each student as a whole. (c) Ventilation and lighting, the classroom teacher emphasizes that these facilities have been around since the classroom is built. It is difficult for teachers to manage them. However, in terms of the smooth entry and exit of air, the teacher always controls it. The lack of ventilation makes the class feel hot and stifling when the weather has high temperature. The absence of a fan in the classroom also hinders students from learning so that more students choose to cool themselves by fanning with paper or student books so that learning is not optimal in the classroom. (d) The arrangement of storing things, the class teacher says that the lack of cabinets in the classroom made the teacher's important files sometimes difficult to keep in the classroom, so the teacher take them home to keep them safe. Student file storage that should have been saved at school is difficult to arrange at classroom. In terms of cleanliness and tidiness in particular, it is still minimal, due to the large amount of trash found in the drawers, the lack of broom facilities, and the lack of student cooperation in performing class pickets.

Regarding the learning outcomes of students, it is obtained from two classes, VA and VB, which consisted of 58 students, only 30 students obtained learning outcomes that met the minimum completeness criteria. If students have comfort in learning, then their interests, attention, motivation, and attitudes can be developed by themselves. Without having to spend a lot of time and energy, the teacher get learning outcomes that match the completeness criteria. So it can be concluded that class management greatly affects student learning outcomes. Based on this background, it triggers to conduct this research deals with the effect of class management on grade five students learning outcome at state primary school number 066654 Kelambir V District Tanjung Gusta Medan Helvetia

According to Cook in Siregar (2019) the first language could be productively utilised in management classroom involving when the teachers organized assignment and rules to be used in the instructional process. Gultom (2020) stated that teacher must be able to manage the class well. The activity of managing the class intends to create and maintain a class atmosphere (condition) so that the learning process takes place effectively and efficiently. Teachers must have teaching skills in order to achieve learning goals and students can understand what is conveyed by the teacher. 


\section{Review of Literatures}

\subsection{Class Management}

Class management generally refers to the skills of educator. Class management consists of two words, namely management and class. Management means leadership. Karwatidan Jonni (2018: 3) explains that of the word management derives from Latin, mantis which means hand and agere means doing. The two words are combined into the verb managere means to handle. The word managere is translated into English in the form of the verb to manage.

Class management is a series of teacher activities to grow and maintain an effective classroom organization. It includes teaching objectives, time management, room and equipment management, and student grouping in learning. According to Mulyasa (2006: 91), class management is a teachers' skill to create a convenient learning climate and control it in case of disruption in learning. It can be defined as the teacher's ability to utilize class potential in the form of providing the widest possible opportunity for each individual to carry out creative and directed activities. Class management is the activity of managing student behavior, so that students can learn.

Class management forms two aspects, students and physical management (rooms, furniture, learning tools). Opening a window so that fresh air can enter the room or so that the room becomes bright, turning on the electric light, shifting the blackboard, arranging the table, is a physical classroom management activity. Receive the same lessons, and come from the same teacher. On the other side, controlling students attitude, motivating students, and creating conducive class room is part of students' class management.

The basic concept that needs to be considered in classroom management is the placement of individuals, groups, schools and environmental factors that influence it. Teacher's duties such as controlling, organizing or disciplining students are inappropriate actions for now. The most important teacher activity is managing, organizing and coordinating all student activities towards learning objectives. Class management is a skill that teachers must have in deciding, understanding, diagnosing and the ability to act towards improving the classroom atmosphere on aspects of classroom management. As for the aspects that need to be considered in classroom management are nature classes, classroom situations, selective and creative action.

Based on this understanding, it can be concluded that class management is an effort that deliberately made to achieve teaching goals. A very simple conclusion is that classroom management is an activity of class management for teaching purposes. Another definition of class management is viewed from the old understanding, namely maintaining class order.

\subsection{Learning Outcomes}

Learning outcomes are the appearance of the learning process that has been carried out. The better the learning process is carried out the better the learning outcomes obtained. The learning outcomes refer to the new behavioral changes of students who are resident, functional, positive, aware and comprehensive, not only one aspect but also integrated as a whole. According to Anitah, et al (2007: 219), learning outcomes are the culmination of a process that has been carried out in learning. Learning outcomes are the attainment of a form of behavior change that tends to persist from the cognitive, affective, and psychomotor domains of the learning process carried out within a certain time. 
According to Uno (2010: 17) learning outcomes are statements that indicate what students might do as a result of their learning activities. Thus, it is something that students achieve or obtain. It is expressed in the form of mastery, knowledge and basic skills found in various aspects of life so that behavior changes in individuals appear. Therefore, it can be concluded that learning outcomes are the final results or competencies that students have acquired after participating in learning activities.

\section{Research Method}

\subsection{Place and Time of Research}

This research is conducted at state primary school number 066654 Kelambir V, it is located at Jl. Kelambir V Gang Satria, District of Tanjung Gusta Medan Helvetia. The implementation of this research is planned on July 2020. The population in this study is students of class five, which consists of two classes, while the sample of this study is taken 2 classes, namely class VA totaling 28 students and class VB totaling 28 students. The total number of class V students is 56 students.

\subsection{Types of Research}

This type of research uses an ex-post facto design. According to Klinger, ex post facto research is a study in which the independent variables have occurred. Classroom management is carried out by class five teachers at state primary school number 066654 Kelambir V, district of Tanjung Gusta Village, Medan Helvetia. It is started with observation of the dependent variable in a study. In ex post facto research, the researcher does not treat the research subject. In accordance with Sugiyono's statement (2015:11) this method is called a positivistic method because it is based on the philosophy of positivism. The philosophy of positivism views reality / symptoms / phenomena. It can be classified, relatively fixed, concrete, observable, measurable, and the symptom relationship is causal.

\subsection{Data Analys is Technique}

The analysis technique used in this research is the simple regression technique which observes the relationship or effect between two or more variables. In quantitative research, the data analysis used is clear. It is directed to answer the problem formulation or test the hypothesis that has been formulated. To test the hypothesis used with the help of a computer program SPSS for Windows version 25.0. In testing the hypothesis, a significance level of $\alpha$ of 0.05 is used.

\subsection{Research Result}

The data in this research is the result of distributing questionnaires about classroom management. In this study, it analyzes whether there is a relationship between variable $x$ (class management) and variable y (learning outcomes) so that it could be seen whether there is a significant relationship between the two variables. The instruments are to be given and filled by students in their homes or a number of children are collected at the researchers' house according to the health protocol. The researcher gave directions to the respondents before filling out the questionnaire because students know directly about and at the same time participate in classroom learning activities.

In data collection, it is used a questionnaire distribution technique that is distributed to students of class VA and VB by using a sample of 56 students. As well as documentation to get information about student learning outcomes obtained by observing 
the daily test scores of students, namely tests 1,2 and 3 . The questionnaire is distributed to students, researchers compile by giving statements as many as 20 items, namely regarding class management. The filling out of this questionnaire is carried out by two classes. It is taught by two different teachers. The teacher of grade VA is Mrs. Astri Sinaga and the teacher of grade VB is Mrs. Nelda Parangin-angin. Class management categories are as follows:

Table 1. Class Management Interval

\begin{tabular}{|l|l|l|}
\hline No. & Interval & Categorization \\
\hline 1. & $0-16$ & Poor \\
\hline 2. & $17-32$ & Less good \\
\hline 3. & $33-48$ & Fairly good \\
\hline 4. & $49-64$ & Good \\
\hline 5. & $65-80$ & Very good \\
\hline
\end{tabular}

The Interval data above shows that the classroom management carried out by the two teachersin the good category. There are 11 positive statements and 9 negative statements.

Learning outcomes are obtained from the daily test scores of students who had been carried out 3 times a month. The scores obtained are added up and the average value of the daily test scores is presented. The following are categories of learning outcomes:

Table. 2. Learning Outcomes Interval

\begin{tabular}{|l|l|l|}
\hline No. & Interval & Categorization \\
\hline 1. & $0-20$ & Very low \\
\hline 2. & $21-40$ & low \\
\hline 3. & $41-60$ & Fairly high \\
\hline 4. & $61-80$ & high \\
\hline 5. & $81-100$ & Very high \\
\hline
\end{tabular}

Interval data above shows that the learning outcomes of students are in the high category. Furthermore, to test the significant effect of class management (X) on learning outcomes (Y), the calculation uses the help of the SPSS version 22.0 for windows program. For the results of the analysis of the effect of class management on students learning outcomes of class five at statem primary school number 066654 Kelambir V District of Tanjung Gusta Medan Helvetia Academic Year 2019/2020 is as follows.

Table 3. Results of Class Management Regression Analysis on Learning Outcomes Coefficients $^{\mathrm{a}}$

\begin{tabular}{|c|c|c|c|c|c|}
\hline \multirow[b]{2}{*}{ Model } & \multicolumn{2}{|c|}{$\begin{array}{l}\text { Unstandardized } \\
\text { Coefficients }\end{array}$} & \multirow{2}{*}{$\begin{array}{l}\text { Standardized } \\
\text { Coefficients } \\
\text { Beta }\end{array}$} & \multirow[b]{2}{*}{$\mathrm{T}$} & \multirow[b]{2}{*}{ Sig. } \\
\hline & $\mathrm{B}$ & Std. Error & & & \\
\hline $1 \quad$ (Constant) & 24,281 & 6,506 & & 3,732 &, 000 \\
\hline Class Management & ,896 &, 119 & ,716 & 7,544 &, 000 \\
\hline
\end{tabular}

a. Dependent Variable: Learning Outcomes 
Based on the results of the regression analysis obtained, the constant value (a) = 24.281 and beta $=0.896$ and the value of $t$ count and the level of significance $=0.000$. The coefficients table obtained the class management variable and learning outcomes with a sig value of 0.000 , and then compared with a probability of 0.05 . From the table above, it is also obtained the calculation equation is $\mathrm{Y}=24.281+0.896 \mathrm{X}$. To test the line coefficient can be seen in the $\mathrm{t}$ and sig columns. From the test results obtained the $\mathrm{t}$ value of 7.544 with sig 0.000 .

Therefore the significant value $<0.005$, it means that class management has a positive effect on learning outcomes. If there is an increase in class management, it will affect the increase in learning outcomes which is equal to 0.896 .

Table 4. Summary Model Test Results

\begin{tabular}{|c|c|c|c|c|}
\hline Model & $\mathrm{R}$ & $\mathrm{R}$ Square & $\begin{array}{c}\text { Adjusted R } \\
\text { Square }\end{array}$ & $\begin{array}{c}\text { Std. Error of the } \\
\text { Estimate }\end{array}$ \\
\hline $\mathrm{I}$ &, $716^{\mathrm{a}}$ &, 513 &, 504 & 6,302 \\
\hline
\end{tabular}

The results of the model summary table in this section show $\mathrm{R}$ of 0.716 and the coefficient of determination (Rsquare) of $0.513 .100 \%=51.3 \%$. (Rsquare) of 0.513 indicates the number of determination (R2). The results of the data also show an Adjusted R Square of 0.504 and a standard Error of Estimate of 6.302, which indicates a measure of the error rate in predicting the related variables. This means that the contribution of class management to learning outcomes is $51.3 \%$ and the rest is influenced by other factors.

To test whether the regression is correct or feasible, it is necessary to test the linearity relationship between variables $\mathrm{X}$ and $\mathrm{Y}$. The numbers used are:

Table 5. Anova Test Result

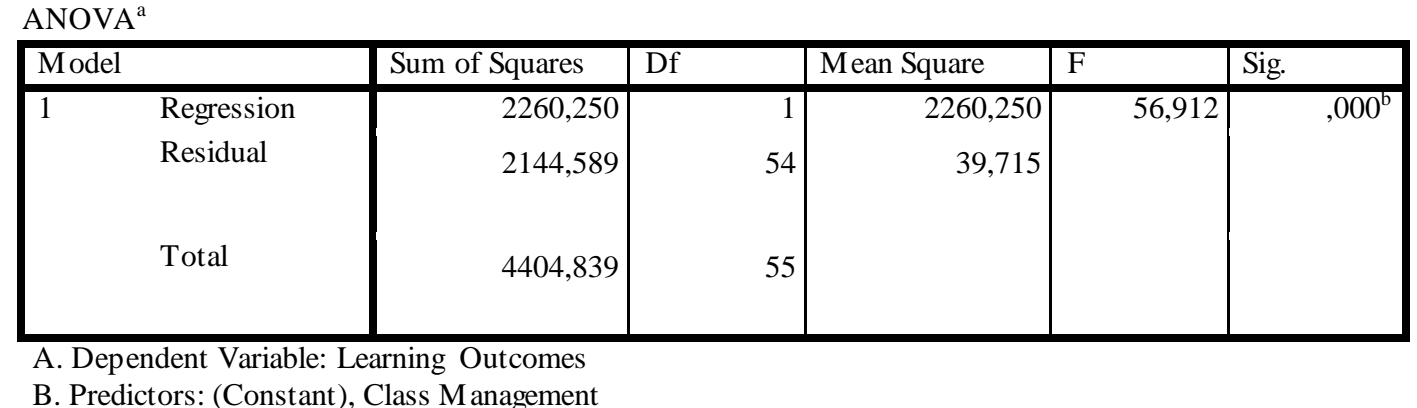

Based on the results of the $\mathrm{F}$ test calculation, the calculated $\mathrm{F}$ value is 56.912 with sig $=0.000<0.005$ so that Ho is rejected and Ha is accepted, which means that there is a significant effect of class management $(\mathrm{X})$ on learning outcomes $(\mathrm{Y})$. This means that the better the classroom management carried out by the teacher, the higher the student learning outcomes. 


\section{Discussions}

Based on the results of data analysis, the results of simple linear regression calculations and the product moment correlation between class management $(\mathrm{X})$ and learning outcomes $(\mathrm{Y})$, the regression equation $\mathrm{Y}=24.281+0.896 \mathrm{X}$ is obtained. The regression equation $\mathrm{Y}=24.281+0.896 \mathrm{X}$ shows that every increase of one unit of $\mathrm{X}$ will result in 0.896 units of increase for Y. In other words, every one unit increase in the independent variable (class management) result in an increase for the dependent variable (learning outcomes) of 0.896.

The regression equation $\mathrm{Y}=24.281+0.896 \mathrm{X}$ with a value of $\mathrm{a}=24.281$ with a positive sign indicates that class five who learns 1,2 , and 3 have good learning outcomes, and vice versa if it is negative this means that class five has not good learning outcomes. In addition, the regression equation also shows the value of $b$ (regression coefficient) of 0.896 with a positive sign, this indicates the increase in the dependent variable (learning outcomes) caused by the independent variable (class management). And the plus sign (+) in the direction number or regression coefficient (b) shows the line generated on the upward regression line.

In simple linear regression analysis, one of the assumptions is linearity. The regression line between the independent variable (class management) and the dependent variable (learning outcomes) forms a linear line or not. Simple linear regression analysis with regression equation $\mathrm{Y}=24.281+0.896 \mathrm{X}$, forming a linear line and coefficient of regression direction means. From the calculation results obtained $\mathrm{F}$ count 56.912 in consultation with $\mathrm{F}$ table $5 \%$ error rate, with $\mathrm{n}=54$ from the formula $\mathrm{df}(\mathrm{n} 1)=\mathrm{k}-1$ so $2-1$ $=1$ and $\mathrm{df}(\mathrm{n} 2)=\mathrm{nk}=56-2=54$ obtained Ftable $=4.02$. Thus $\mathrm{F}$ count $>\mathrm{F}$ table $(56.912>$ 4.02) for an error level of 5\%. The regression direction coefficient means, this shows that learning outcomes at $\mathrm{KD} 1, \mathrm{KD} 2$, and $\mathrm{KD} 3$ are significantly dependent or influenced by class management. So it can be concluded that there is a positive and significant influence between class management on student learning outcomes. Thus, the hypothesis which states the better classroom management is carried out by the teacher, the higher learning outcomes of fifth grade students at state primary school is received.

The value of correlation $r_{x y}=0.716$ indicates that the level of relationship or the effect of classroom management on learning outcomes is quite high. The magnitude of the influence of class management on student learning outcomes shows that the more optimal classroom management is carried out affects student learning outcomes. To optimize classroom management, classroom management principles can be used as follows: (a) Warmth and enthusiasm in teaching, (b) using words or actions that can challenge students to think, (c) The teacher can make variations; (d) The flexibility of teachers in carrying out tasks needs to be improved, (e) Cultivating self-discipline is the basis of teacher capital, and (f) Emphasis on positive things needs attention.

As for the contribution or effect of class management on learning outcomes, according to the results of the calculation of the coefficient of determination R2 $=0.513$ is obtained. This means that the magnitude of the influence or contribution of class management $(\mathrm{X})$ on learning outcomes $(\mathrm{Y})$ is $51.3 \%$ and $48.7 \%$ of student learning outcomes are influenced by other factors.

Thus, class management $(\mathrm{X})$ on learning outcomes $(\mathrm{Y})$ has a positive influence. This means that the rise and fall of the dependent variable (Learning Outcomes) is caused by the independent variable (Class Management). If class management is carried out 
optimally, it affects the high student learning outcomes, but if class management is not optimal, it affects the low student learning outcomes.

\section{Conclusions}

Based on the results of statistical analysis in this study, it can be concluded that there is a significant influence between class management and student learning outcomes. This is evidenced by the results of research which show that simple linear regression analysis with the regression equation $\mathrm{Y}=24.281+0.896 \mathrm{X}$, forms a linear line and the coefficient of regression direction means. From the calculation results obtained $\mathrm{F}$ count 56.912 in consultation with $\mathrm{F}$ table for an error rate of $5 \%, \mathrm{~F}$ table $=4.02$. Thus $\mathrm{F}$ count $>\mathrm{F}$ table (56.912> 4.02) for an error level of 5\%. The regression direction coefficient means that it shows that learning outcomes in tests 1,2 , and 3 are significantly dependent or influenced by classroom management.

As for the contribution or influence of class management on learning outcomes, according to the results of the calculation of the coefficient of determination $\mathrm{R} 2=0.513$ is obtained. This means that the magnitude of the influence or contribution of class management $(\mathrm{X})$ on learning outcomes $(\mathrm{Y})$ is $51.3 \%$ and $48.7 \%$ of student learning outcomes are influenced by other factors. Based on the results of the F test calculation, the calculated $\mathrm{F}$ value is 56.912 with sig $=0.000<0.005$ so that $\mathrm{Ho}$ is rejected and $\mathrm{Ha}$ is accepted, which means that there is a significant effect of class management $(\mathrm{X})$ on learning outcomes (Y). This means that the better the classroom management carried out by the teacher, the better the student learning outcomes. So it can be concluded that classroom management carried out by VA and VB teachers is good categorization.

\section{References}

Anitah, Sri, W, et al. 2007. Learning Strategies in Primary School. Jakarta: Universitas Terbuka.

Dimyati, Mudjiono. 2013. Learning and Study. Jakarta: PT. Rineka Cipta.

Djamarah, Bahri Syaiful and Aswan Zain. 2006. Teaching and Learning Strategies. Jakarta: PT. Rineka Cipta.

Gultom, S., Hutauruk, A.F., and Ginting, A.M. (2020). Teaching Skills of Teacher in Increasing Student Learning Interest. Budapest International Research and Critics Institute-Journal (BIRCI-Journal) Vol 3 (3): 1564-1569.

Kadir. 2015. Applied Statistics Concepts, Examples and Data Analysis with the SPSS / Lisrel Program in Research. Jakarta: PT. Raja Grafindo Persada.

Karwati, Euis and Donni Juni Priansa. 2018. Classroom Management Professional teachers who are inspiring, creative, fun, and outstanding. Bandung: Alfabeta.

Karwati, Euis and Donni Juni Priansa. 2013. Performance and Professionalism of Principals. Building quality schools. Bandung: Alfabeta.

Mulyasa. 2006. Becoming a Professional Teacher Creates Creative and Fun Learning. Bandung: PT Remaja Rosdakarya.

Siregar, M. (2019). Pedagogical Translation Use by Scientific Approach in Teaching English. Budapest International Research and Criticsin Linguistics and Education (BirLE) Journal Vol 2 (4): 111-119.

Sugiharto (2020) Geographical students' learning outcomes on basic political science by using cooperative learning model with Group Investigation (GI) type in State 
University of Medan, Indonesia, Journal of Human Behavior in the Social Environment, 30:4, 447-456, DOI: 10.1080/10911359.2019.1696261.

Sugiyono. 2015. Combined Research Methods (Mixed Methods). Bandung: Alfabeta.

Sukmadinata, Nana Syaodih. 2005. Educational Research Methods. Bandung: Pemuda Rosda Karya.

Syaiful, Zain, and Aswan. 2006. Teaching and Learning Strategies. Jakarta: Rineka Cipta.

Syah, Muhibbin, 2008. Educational Psychology with a New Approach. Bandung: PT Remaja Rosda Karya.

Uno, Hamzah B. 2010. Theory of Motivation and its Measurement. Jakarta: PT Bumi Aksara. 